\title{
NEW MISCELLANEOUS CHALCIDOID HYMENOPTERA. WITH NOTES ON DESCRIBED SPECIES.
}

\author{
By A. A. Girault.
}

\section{Ablerus peruviana new species.}

\section{Female: Length, about $1.10 \mathrm{~mm}$.}

Ovipositor half the length of the abdomen, white tipped. Dark metallic green, the following parts silvery white: Vertex, scape except bulb and middle, apical half of the pedicel, funicles 2 and 4, trochanters, knees, tips of tibiæ and middle three joints of the tarsi. Venation dusky, base of marginal vein and the stigmal vein pale. Fore wings with a distinct, oblique (caudo-distad), sooty cross-stripe from the distal two-thirds of the marginal vein and the side of the stigmal. Marginal fringes of the fore wing short, the longest not an eighth of the greatest wing width. Pedicel somewhat longer than wide, barely shorter than funicle 1 which is over twice longer than wide; funicle 2 thrice longer than wide and longest, 4 slightly shorter than 2,3 slightly longer than wide. Club longer than the two preceding joints combined. Mandibles tridentate.

The male is about the same but the antennæ are wholly black; funicle 3 wider than long, the others subequal and nearly thrice longer than wide; club unjointed, longer than the funicle joints (any one).

From a pair on a slide in the U. S. N. M., from Coscomba, Peru (C. H. T. Townsend).

Types: Catalogue No. 19929, U. S. N. M., the above specimens.

\section{Pentastichus xanthopus Ashmead.}

The antennæ are as in Tetrastichus, the two ring-joints rather large and distinct but the club is only 2 -jointed and with a short terminal nipple. Sculpture usual. Fore wings as in Tetrastichus, the marginal fringes barely longer than usual ( $i$. e e, not extremely short). Venation yellow. Thorax as in Tetrastichus. Dark metallic green. Legs and antennæ golden yellow. Propodeum short, with at least a median carina. Funicle joints subequal, but 1 a little longer than wide, 2 and 3 each a little wider than long. The genus is valid. Original description otherwise correct.

From 1 ๙, 2 क types in U. S. N. M. ( $q$ wings, 3 antennæ and head on a slide). 
Ablerus perspeciosus new species.

Female: Length, $0.65 \mathrm{~mm}$., excluding the ovipositor which is white at tip and extruded for a length equal to a fourth of the abdomen.

Like capensis Howard but may be distinguished from that species in that the fore wings bear a third fuscous patch which is proximad from the base of the marginal vein and which is long-cuneate and densely ciliate; it is oblique and extends nearly to the middle of the second infuscation, a broad cross-stripe which differs in shape from the one in capensis, being straight with parallel margins, narrowing to a sort of neck cephalad, the neck against the base of stigmal vein and bearing a dense patch of black bristles; the distal cross-stripe is also different, shaped like an inverted ? but without the dot (it is like a spread bat in capensis). Moreover, the legs are concolorous except the knees, tarsi (except joint 5) and distal half of all tibiæ. Head white with a cross-stripe of brown-black across below the eyes. Scape (except at base and a broad middle portion), distal half of the pedicel, funicles 2 and 4, silvery. Funicle 3 a little longer than wide, 1 and 4 subequal, twice longer than wide (4 stouter and not quite that length), 2 slightly shorter than 1. Pedicel barely shorter than funicle 1 . Parapsides white at distal apex. Cephalic tibiæ all dusky save at tip.

Described from four females on a slide labelled "from Diaspis pentagona. Nishigahara, Japan, July 16, 1909. S. I. Kuwana, No. 33."

Types: Catalogue No. 19930, U. S. N. M., the above specimens.

\section{Habrocytus obscuripes Ashmead.}

Resembles Aetroxys callidii Ashmead but that species has pubescence as in Catolaccus and the postmarginal vein is distinctly shorter than the marginal (mandibles not examined). Colored like Rhopalicus coloradensis Ashmead but more slender, the parapsidal furrows slightly longer and slightly more complete in that species and funicle 1 there is about twice longer than wide, here only about a half longer than wide; also in the larger species, there is an obtuse cross-carina on the distal scutellum. The mandibles are alike in both, 3- and 4-dentate. Somewhat like Cecidostiba dendroctoni Ashmead but the latter has both mandibles tridentate, the incomplete parapsidal furrows are more meso-transverse and the antennæ more slender, the funicle joints longer, 1 over thrice longer than wide, 2 and 3 each nearly as long as 1 .

Many specimens reared in connection with the strawberry weevil, St. Paul, Minnesota (S. Marcovitch). The scutellum is simple. 
Cirrospilopsis fuscipennis new species.

Female: Length, $1.00 \mathrm{~mm}$.

Orange yellow, the abdomen dusky but the incisions of the segments showing through as dull yellow; meson of propodeum and last two pairs of tibiæ, blackish. Fore wings hyaline but with a conspicuous smoky cross-stripe from the marginal vein, the apical margin of which slopes distad from the apex of the stigmal vein for a length about equal to that vein, then slopes back, thus a cone; its proximal margin is nearly straight and a little distad of the origin of the marginal vein. Venation dusky yellow, the marginal vein nearly as long as the submarginal, over thrice the length of the rather long stigmal, the latter a third longer than the postmarginal. Marginal cilia of the fore wing distinctly longer than usual, about somewhat longer than a fourth the greatest wing width. Marginal vein with long bristles. Mandibles 5-dentate. Pedicel a half longer than wide at apex, longer than either funicle joint of which 2 is subglobular, 1 somewhat longer than wide. Terminal nipple of club small, distinct. Caudal wings where broadest with about eight lines of discal cilia. Head and thorax finely reticulated. Propodeum with a median carina and no others. Club rather large. Abdomen longer than the thorax. Fourth joint of the tarsi black.

Described from one female captured September 11, 1915, by sweeping meadows at Glenndale, Prince George County, Maryland.

Type: Catalogue No. 19931, U. S. N. M., the above specimen on a tag, the head, a hind leg and the fore wing on a slide.

\section{Uscanopsis new genus.}

Female: In my table to the Ophioneurini runs to Uscanoidea Girault but differs from that genus in bearing two ring-joints in the antennæ and both the marginal and stigmal veins are distinctly longer, the stigmal vein with a distinct, rather slender neck, the oblique line of cilia from the stigmal vein is present (not isolated but limiting the discal ciliation proximad). Marginal vein somewhat over half the length of the submarginal. Club conic-ovate, with rather long, scraggly hairs, its second joint much the longest, joint 1 much wider than long. Caudal wings short and broad, with three lines of discal cilia, the fainter one caudad, the others paired. Male the same but the club shorter. Discal ciliation of fore wing normal, that is, not in regular lines, not so dense as in Tumidifemur. Tarsal joints short. Cephalic tibial spur minute, straight, the caudal one elongate, three-fourths the length of the tarsus. Club articulation not very distinct. Otherwise as in the named genus.

Uscanopsis carlylei new species. Genotype.

Female: Length, $0.60 \mathrm{~mm}$.

Black, the head and thorax (except a cuneate marking from cephalic margin of scutum to distal fourth and the disk of the parapsides) orange yellow, the fore wings infuscated lightly from the bend of the sub- 
marginal vein distad indeterminately a little beyond the venation, the latter dusky. Legs dusky except articulations, tips of tibiæ (more broadly in the cephalic ones) and the tarsi. Club two and a third times longer than wide at base, terminating in a pair of the rather long setæ. Marginal cilia of the fore wing short but not extremely so, distinct, the fore wing shaped about as in Trichogramma. Mandibles equally tridentate. Body as in Pterygogramma. Middle tibial spur slender, slightly less than half the tarsal length, the caudal one rather stout. Male the same, the abdomen more blunt at apex.

Described one male, five females on a slide labelled "53-42. Reared from egg-mass of Membracis tectigera. Port of Spain, British West İndies, March, 1915, F. W. Urich."

Types: Catalogue No. 19932, U. S. N. M., the above specimens on a slide. A second slide with fragments retained as paratypes.

\section{Oligosita oophagus new species.}

\section{Female: Length, $0.70 \mathrm{~mm}$.}

Bright golden yellow, the eyes darker, last tarsal joint black, the metapleurem with a longer than wide, oblique black spot. Differs from americana in that the funicle joint is distinctly longer than wide, the fore wings broader and with more discal ciliation, the pedicel more slender and so on. From comosipennis in that the fore wings are not so broad, the color much lighter, the pedicel a little more slender. The male differs in bearing a broad black band across the abdomen just distad of the middle. Distal edge of fore wing embrowned.

Described from six males, twelve females reared from an egg-mass of a leaf-hopper embedded in a leaf of sugar cane, Diego Martin, British West Indies, January, 1914 (F. W. Urich).

Types: Catalogue No. 19933, U. S. N. M., two males, four females on a slide. Six females on another slide, the same number, as paratypes.

Oligosita comosipennis in Girault, 1914 (Canadian Entomologist, p. 328) is no doubt this new species.

Achrysocharis partifuscipennis new species.

\section{Female: Length, $0.55 \mathrm{~mm}$.}

Dark metallic green, the abdomen black, the legs white except caudal coxæ and bases of the other coxæ; scape pale along about its proximal half. Fore wings hyaline, with a distinct yet faint cross-stripe from the whole of the marginal and stigmal veins, the venation dusky yellowish, the postmarginal vein shorter than the stigmal. Mandibles tridentate. Caudal wings with about five lines of discal cilia where broadest. Head and thorax uniformly scaly, the propodeum smoother, with no median nor lateral carinæ. Parapsidal furrows complete. 
Marginal fringes of the fore wing of moderate length, the longest about a third of the greatest wing width, the discal cilia of the fore wing limited proximo-caudad by a regular line of cilia. Pedicel a half longer than its greatest width (before apex), subequal in length and width to funicle 1 ; rest of flagellum slenderer, filiform-acuminate. Funicle 2 twice longer than wide, longer than club 1 , subequal to club 2 , club 3 longest of the flagellum, acuminate, three and a half times longer than its greatest width (not far from base) and terminating in a long, distinct spine which is about half of its length. Fore wings obtusely rounded at apex,
moderate to narrow.

Differs from Achrysocharella americana (types compared) in having the more slender, tapering flagellum, the darker scape, smaller mandibular teeth, infuscated wings and so forth.

Described from one female captured by sweeping meadows at (Hillmead) Glenndale, Prince George County, Maryland, September 11, 1915.

Type: Catalogue No. 19934, U. S. N. M., the above specimen on a slide.

\section{Epitetrastichus marylandensis new species.}

\section{Female: Length, $1.65 \mathrm{~mm}$.}

Orange yellow, the abdomen and legs yellowish brown, the following black portions: Face of pronotum centrally, flagellum and five pairs of cross-stripes on the abdomen, the second stripe of each pair abbreviated except the distal pair which is a little distance before apex. Second stripe of first pair much abbreviated, merely a transverse dash across meson, that of the fourth pair longer than that of 2 and 3 and projected a little proximad at the meson; that of pair 2 joined along the meson to the first stripe of pair 3 . Ovipositor valves black. First pair of crossstripes near base. Meson and cephalic margin of propodeum dark brown, the propodeum very short at the meson, with a carina there but no others. A line of short, black setæ across caudal margin of pronotum and lateral margin of the scutum. Apex (cephalad) of axillæ a little dusky, otherwise about as in cuneiformis (in death, the dorsal abdomen of the latter appears black except at base and just before apex; its propodeum is longer at the meson but not long). Distal half of scape dusky. Terminal nipple of club minute, smaller than with cuneiformis.
Mandibles tridentate.

Described from one female captured by sweeping meadows at Glenndale, Prince George County, Maryland, September

Type: Catalogue No. 19935, U. S. N. M., the above specimen on a tag, the head on a slide. 
Aprostocetus whitmani new species.

\section{Female: Length, $2.00 \mathrm{~mm}$.}

Very dark metallic purple, the wings hyaline; scape, a little less than the proximal fourth of the abdomen (except along the latero-dorsal margin rather broadly) and the legs except all coxæ and first two pairs of femora (except at tip). Venation pale. Scape stout, its short bulb purple; pedicel a little longer than wide at apex, a little longer than club 3. Ring-joint large. Funicles 2 and 3 subequal, each twice longer than wide, stout, 1 somewhat shorter, longer than the pedicel. Club 3 with a distinct terminal nipple; club 1 a little shorter than funicle 1 , longest of the club by a little. Mandibles tridentate. Sculpture usual; a line of rather obscure punctures along the lateral margin of the scutum. Propodeum and abdomen densely finely scaly, the former longer laterad, with a distinct median carina and a very delicate, short, curved lateral one from caudad (half or less complete). Cephalic femora more broadly white at tip. Pedicel whitish, purple above at base. No postmarginal vein, the stigmal moderately long. Abdomen conicovate, pointed, somewhat longer than the rest of the body. Fore wings broad.

The male is the same but the abdomen is oval, flat and short, the scape compressed and dilated (uniformly, nearly, for its entire length), purple above and below, the funicle is white, also the club except the distal joint. Also, the cephalic femur is purple only dorsad centrally and the middle one only centrally. The funicle is 4 -jointed, the club 3 -jointed and as in the female except the middle joint is longest. Funicles 1-2 subequal, a half longer than wide, 2-3 subequal, each nearly twice longer than wide. Club 2 subequal to funicle 2 .

Described from one male, eight females, reared from the eggs of Physonota unipunctata, St. Paul, Minnesota (S. Marcovitch).

Types: Catalogue No. 19936, U. S. N. M., the above specimens on three tags plus a slide bearing a male and female head.

Rhopalicus americanus new species.

Female: Length, $3.00 \mathrm{~mm}$.

Bright metallic green, the legs, scape and pedicel reddish yellow tinged centrally with brownish, the venation yellow, the fore wings with a large fuscous blotch from the whole of the marginal vein, this blotch oblique, rectangular (longer than wide, its sides parallel, its apex reaching slightly beyond the middle of the wing and fainter). Head and thorax very finely punctate, the clypeus bidentate at apex. Antennæ inserted slightly below the middle of the face, 13-jointed with two ring-joints (the second the larger), the club short, ovate; funicle 1 a half longer than wide, subequal to the pedicel, 2 a little shorter than it, 3 and 4 subequal, each slightly longer than wide, the rest quadrate. 
Marginal vein subequal to the elongate stigmal, somewhat shorter than the postmarginal. Cephalic femora but moderately swollen. Parapsidal furrows just indicated cephalad. Propodeum of moderate length, with a median carina and no others except short rugæ from its cephalic margin; no spiracular sulcus. Cephalic coxa metallic at base laterad, hind coxæ all metallic. Propodeum without a neck, its caudal margin rimmed. Abdomen produced beneath, conic-ovate. Mandibles tridentate.

Described from one female in the U. S. N. M., "Agricultural College, Michigan, 7-26-1890."

Type: Catalogue No. 19937, U. S. N. M., the above female plus a slide bearing a head, a hind leg and a fore wing.

\section{Coccophagus cinguliventris Girault.}

Male: In the male the yellow band on the abdomen is very short, subobscure; the head and thorax more brownish. One male, two females reared from Lecanium corni at Madison, Wisconsin, June 22, 1915. (F. A. Fenton.)

ARTHOLYTIS APATEL $Æ$ and A. PIMPLE Ashmead are synonyms. The median carina of the propodeum is delicate. There is a round fovea at cephalic margin of propodeum at mesal base of the delicate lateral carina. The propodeal spircale is round, small. The second ring-joint is larger than the first; funicle joints widening distad, 6 largest, all wider than long and much shorter than the pedicel.

\section{Gonatocerus triguttatus new species.}

\section{Female: Length, $0.85 \mathrm{~mm}$. The ovipositor slightly extruded.}

Dull honey yellow, the wings hyaline, the following parts black: Ocellar area, dorsal and ventral edges of the scape, flagellum, marginal and stigmal veins, abdomen, three round spots on thorax, the mesal one between the axillæ and ends of the parapsidal furrows (not on the scutum), the lateral ones on the axillæ cephalad and laterad. Tibiæ darker than the rest of the legs, but not much more so. Scape considerably but not greatly convexly dilated ventrad. Pedicel short, only slightly longer than wide, shorter than funicle 1 which is subequal to 2 and longest (or slightly shorter than 2 which is thrice longer than wide); funicle 3 subequal to 1 , the others shortening in succession, 8 slightly longer than wide. Fore wings of moderate width, their marginal cilia moderately short, about an eighth of the greatest wing width. Head and thorax glabrous. Scutum with an embrowned triangular scalelike area on each side of the meson cephalad. Propodeum with a pair of delicate median carinæ, widely separated and a distinct, curved "lateral carina" which originates caudo-laterad of the minute spiracle. Scutellum separated from the scutum by a transverse sclerite which runs caudad of the axillæ and is longer than the postscutellum. Caudal wings narrow. 
The male the same but the three spots on middle thorax are more or less connected transversely (they are in a line in both sexes), the scutellum is all black except its margin all around, the scutum is entirely black and on each parapside there is an exclamation-point-shaped marking at cephalic margin, this transverse and with the thickened end laterad (sometimes present in the female). The abdomen is yellow, striped with black. Scape very short, the pedicel extremely so; funicle joints lengthening distad, the longest about thrice longer than wide; club joint distinctly longer than funicle 1 .

Described from one male, seven females reared from an eggmass of a leaf hopper on orange, Caroni, British West Indies, February, 1913 (F. W. Urich).

Types: Catalogue No. 19938, U. S. N. M., the above specimens on tags.

Habrocytus quinquefasciatus new species.

Female: Length, $3.25 \mathrm{~mm}$.

Dark metallic green, the propodeum bright green, the wings hyaline, the venation, abdomen, pedicel and basal half of funicle 1 , reddish yellow; legs and scape light yellow. Abdomen with five distinct metallic blackish cross-stripes, the first thinnest, at apex of segment 2,5 at apex, 4 as long as 5 and apparently across the middle of segment 6 , 3 mostly on the basal four-fifths of segment 5 . Tip of ovipositor valves black. Mandibles 3- and 4-dentate. Head and thorax finely punctate, the clypeus striate, incised medially. Segment 2 of abdomen occupying nearly a third of the surface, smooth, rest of abdomen finely scaly along cephalic margin of the segments; a little scaliness on segment 2. Scutellum without an obtuse cross-carina. Propodeum with a distinct median carina, no lateral one but there is an obscure cross-carina from the median one cephalad to the spiracle and short longitudinal carinæ from the cephalic margin to this and dividing foveæ (extending for a little over half way to the spiracle from the meson). Also on the short neck there are short carinæ. Spiracle of propodeum longer than wide; of moderate size. Antennæ inserted below the middle of the face yet slightly above the ventral ends of the eyes, 13 -jointed with two ringjoints; funicle 1 elongate, widening distad, over twice longer than wide at apex, distinctly longer than the rather long pedicel which is twice longer than wide, slender, 6 wider than long, 4 quadrate; second ringjoint twice the length of the first. A marginal spot on the abdomen a little distad of middle of segment 2. Parapsidal furrows about twothirds complete, not deep. Marginal vein slightly longer than the elongate stigmal, the latter a little shorter than the postmarginal.

The male is the same but the abdomen has a broad white stripe across it some little distance out from base (longer than the basal black and extending a little beyond segment 2 , the latter longer than in the female) followed by a cross-stripe of black which is narrow and 
divided along the meson, then by a second, very narrow white stripe, thence black. The obscure cross-carina on propodeum here absent. Antennæ with the pedicel slightly longer than wide.

Described from a single pair labelled " $3816^{\circ} 1$, March 6, 1886." Eastern United States.

Types: Catalogue No. 19939, U. S. N. M., the pair on a tag plus a slide bearing a female head, fore wing and hind tibiæ and a male antenna.

Anastatus aureicorpus new species.

Female: Length, $4.00 \mathrm{~mm}$., excluding the ovipositor, which is extruded for a length equal to a half that of the abdomen.

Reddish brown or orange, the club black, the scutum between the lateral ridges and caudad of the cephalic triangular piece, dark metallic purple; ovipositor valves soiled yellowish (but most of apical part missing). Fore wings with a reddish brown stripe across them from the bend of the submarginal vein to apex of stigmal, this stripe fading near caudal margin. Funicle 1 quadrate, 2 subequal to the pedicel, longest, thrice longer than wide, 3 and 4 subequal, each slightly shorter than $2 ; 8$ slightly longer than wide, larger than 2 . Club short, obliquely truncate from base of joint 3. Ocelli in small metallic spots. Caudal coxæ and funicles 1-3 darker. Postmarginal vein short, slightly longer than the stigmal. Raised triangular-piece of the scutum and the somewhat separated axillæ more coarsely scaly than the rest of the body, the scutellum with scattered, short black setæ. Face above the antennæ with grayish, stiffish pubescence (longer along the eyes). Segments of abdomen with straight caudal margins. Abdomen as long as the thorax.

Described from one female on a tag labelled "Austin, Texas, Carl Hartman" and reared from what appears to be a syrphid puparium.

Type: Catalogue No. 19940, U. S. N. M., the above specimen on a tag.

\section{Abbella subflava Girault.}

Five females reared as hyperparasites of Polynema eutettexi, from beet leaf-stems, August 28, 1915, Spreckels, California. The cheeks and sides of the thorax were dusky; otherwise like the types and probably a variety.

\section{Crataepus fletcheri Ashmead.}

As described. Cephalic tibiæ with a strong, black, bifurcate tibial spur. Antennæ short; scape like a rather long pedicel, the latter somewhat shorter than the scape, slightly longer than wide at apex; funicle joints all hemispherical and wider than long, 1 largest, 2 and 3 subequal; club 3-jointed, not as long as the funicle, its first joint half, its last joint 
small, distinct, with three minute, acute nipples at apex. Three ringjoints of which the middle is largest, distinct. Postmarginal vein absent, the stigmal long. Scutum with a median groove, flat, the scutellum with four. Pronotum flat, large. Antennæ 11-jointed, the funicle and club each 3-jointed.

From the type in the U. S. N. M. (a fore leg and antenna on a slide).

\section{Ceranisus flavopictus Ashmead.}

The types are unrecognizably mutilated but the female scape (the only part of the antennae present) shows no dilation and the marginal fringes of the fore wing are short and usual. The color appears to be wholly black. The species is hopeless.

\section{Sympiesomorphelleus whitmani new species.}

Female: Length, $1.85 \mathrm{~mm}$.

Reddish brown, the wings hyaline, the abdomen and legs (also scape) yellowish brown; the following black parts: Center of occiput, ocellar area, flagellum and apex of the scape, pronotum (except the neck), cephalic fourth of scutum (except along the meson narrowly), axillæ, scutellum laterad of the groove, propodeum lightly distad (its welldefined neck) and along the meson and the margins of the abdomen from base to about middle (but broken in two places). Also the postscutellum and a narrow line from the spiracle on the propodeum. Median carina of the propodeum forming an $\mathrm{X}$ whose distal arms are very long, the carinæ joining not far distad of their origin; no lateral carina. One spur of hind tibiæ small. Mandibles 7-dentate. Pedicel somewhat longer than wide, shorter than any funicle joint; funicles 1-3 subequal, each about thrice longer than wide, 4 slightly shorter, club joints about equal in length, 1 about twice longer than wide, 2 terminating in an acute, spinelike point. Flagellum filiform. Thorax scaly reticulated. Grooves of scutellum practically joined around the apex. Postmarginal vein much longer than the stigmal, the marginal long.

Described from a female in the U. S, N. M., labelled " 174 . Gifu, Japan, Y. Nawa Collection."

Type: Catalogue No. 19941, U. S. N. M., the above specimen on a tag, the head and hind legs on a slide.

\section{Cheiloneurus albicornis Howard.}

Differs from the original description of albicornis Howard as follows: The middle tibiæ are purple except at tip and a silvery area just before base; the caudal femur interiorly has a middle silvery streak along its distal half or more (in some specimens); in some specimens the middle tibia is silvery along its distal half. The scape is distinctly dilated but not greatly. 
The male is wholly blue, the wings hyaline, the legs except the last tarsal joints and most of the caudal tibiæ and the antennæ except scape and pedicel, pale yellow. Club solid, the flagellum clothed with whorls of long hairs. Pedicel very short. In the type female, the middle tibia is dark just below the knee.

One male, seven females reared from Pulvinaria spp. on Poison Ivy, Madison, Wisconsin and from Physokermes picece on Picea abies. The mandibles in all specimens were as in Cristatithorax.

In the male, funicles 1 and 6 are longest, nearly thrice longer than wide, shorter than the club; funicles 2 and 3 subequal, shortest, the joints widest a little out from the base. Club five times longer than wide, or more.

\section{Ooctonus quadricarinatus new species.}

\section{Male: Length, $1.30 \mathrm{~mm}$.}

Propodeum with a pair of median carinæ which diverge widely to middle, then converge to apex, forming a large diamond; its caudal and cephalic margins carinated; and a strong lateral carina which from cephalad runs meso-caudad for over half way, joining (or nearly) the lateral angulation of the diamond of the median carinæ, thence for a short distance latero-caudad to apex; this shorter arm forms therefore a rather small, distinct diamond-shaped areola. Lateral margin also strongly carinated and between this and the minute spiracle runs a long, oblique, smooth groove. Propodeum and postscutellum glabrous; rest of thorax strongly scaly. Scutellum divided by a semi-circular cross-suture whose apex is proximad of the middle, the convexity facing cephalad. Lateral margin of postscutellum carinated. Head finely scaly. Abdominal petiole long, somewhat longer than the caudal coxæ. Black, the wings hyaline, their venation black; tarsi, knees, tips of tibiæ rather broadly and scape and pedicel, more or less reddish brown. Characterized by the very broad fore wings which are subtruncate at apex and bear about 38 lines of very fine discal cilia where widest, the longest marginal cilia not a tenth of the greatest wing width. Caudal wings with 4-5 lines of discal cilia. Pedicel a little longer than wide; funicle joints six or more times longer than wide, the club shorter but somewhat longer than funicle 1. Proximal tarsal joint much the longest. Venation elongate.

Described from three males reared in connection with bark beetles (from limbs of pine infested with Pityogenes hopkinsi) August 16, 1915, New York. The locality is Syracuse.

Types: Catalogue No. 19942, U. S. N. M., the above specimens on a slide. 
Anicetus chinensis new species.

Female: Length, $2.00 \mathrm{~mm}$. Ovipositor extruded a short distance.

Differs from the genotype in being larger, in being deep orange in color with the disk of the abdomen and a broad line down propodeum between the spiracle and meson, deep metallic purple. The antennæ are purple suffused with yellowish. Fore wings yellow from a little before the bend of the submarginal vein distad to near apex, the distal margin of this yellow flatly convexed and browner like a ring (as in the Australian felix). Mandibles with three distinct, equal, acute teeth. Frons subprominent, the great inflexion of the face with an acute, convex, dorsal margin. Frons moderately narrow, a little over thrice the diameter of the cephalic ocellus. Cheeks as long as the eyes. Axillæ with a carina between them. Pedicel greatly concaved and winged at apex. Differs further from ceylonensis in the larger pedicel. Funicle with a backbone, the joints given off as so many vertebræ, the first much narrower than the last which is as wide as the club. Marginal vein thrice longer than wide, the stigmal a little shorter than it, a fourth longer than the postmarginal. Frons with several rows of shallow punctures (caudo-cephalad). Pronotum transverse, the middle of its cephalic face purple. Head and thorax very finely sculptured, giving a velvety sheen. Margin of abdomen at base purple. Thorax with scattered, obscure setigerous punctures. External valves of ovipositor purplish. Tibiæ setose. Hairless line of fore wing with many lines of cilia proximad of it. Caudal wings broad (about 25 lines of rather fine discal cilia). There is a dusky line across the face as in felix and the genotype.

Described from one female on a tag from China and reared from a Lecanium (Compere).

Type: Catalogue No. 19943, U. S. N. M., the above specimen plus a slide bearing the head and a pair of wings.

The genotype has the club obliquely truncate from the base of the third joint and the scape is edged with black ventrad; the marginal vein is about twice longer than wide, somewhat shorter than the stigmal. The mandibles were missing in the single specimen. The caudal wings are hyaline excepting for a longovate, fuscous spot just under the apex of the venation; they bear about 22 lines of discal cilia where broadest.

The genus Habrolepopterygis Girault is a synonym of Anicetus.

Sympiesomorphelleus bicoloriceps new species.

Female: Length, $2.25 \mathrm{~mm}$.

Lemon yellow, the wings hyaline, the body marked with black as follows: Upper half or more of head except a flat triangular area on vertex against the eye, a median stripe up the occiput (upper part) to vertex, cheek right under apex of the eye and a spot on face against the 
eye; a rather broad, oblique stripe down propodeum through the spiracle (forming a $\mathrm{V}$ but the letter not quite joined at apex); ovipositor
valves, a spot on each obovate stripe from base of meson of abdomen at apex and a long(widest at about the middlewn meson of the abdomen to distal sixth third of hind tibire middle of the abdomen). Flagellum and distal longer than wide; funicle 1 twice longer than wide, somewre 1 twice longer than wide, longest, 4 a half subobsolete, its joint longer longer than club 1 ; terminal nipple of club the length of the stigmal, than the pedicel. Postmarginal vein twice Pronotum, scutum, parapsides and a half the length of the marginal. of segments) distad of segment 2 dorsal abdomen (except distal edges tellum glabrous and so the rest 2 rather coarsely reticulated, the scudelicate median carina which the thorax. Propodeum with a pair of lateral carina, the spiracles reniform at base (cephalad) and no true of the two bristles on that side of the Gcutellum. Segmellum just mesad occupying a fourth of the surface. Head and cephents 2 of abdomen scattered, rather long hairs. Antennæ inserted cephalic thorax with ends of the eyes.

Described from two females on tags in the U. S. N. M., labelled "From Tinea on Solanum, August 11, 1886, C. V.
Riley."

Types: Catalogue No. 19944, U. S. N. M., the above specimens and a slide bearing a fore wing, hind tibiæ and antennæ.

\section{Miotropis platynotæ Howard.}

This is a species of Sympiesomorphelleus. Propodeum with a delicate paired median carina and a curved lateral one. Scutellum distinctly scaly but not as coarsely as the scutum. Brown margins of the abdomen indefinite, the dusky spot of the disk also, often absent. Mandibles 8 -dentate. Funicle 1 twice longer than wide, 4 a fourth shorter. Terminal spine of club distinct but not large. Pedicel shorter than funicle 4 .
From the female types (hind tibiæ and head mounted on a slide).

\section{Stigmatotrastichus new genus of the Ceratoneurini.}

Female: Head flattened or very thin, concaved, longer than wide, the antennæ inserted below the middle of the face yet above the ventral ends of the eyes, the vertex elevated. Pronotum large, conical, as long as the peltate scutum, the latter simple. Scutellum with four delicate grooves; abdomen with a distinct, quadrate petiole, flattened above, not so long as the thorax. Propodeum large, with a delicate median Marginal vein long, as a weak lateral carina directly from the spiracle. thickened at base, the thickened submarginal and distinctly, conically length of the entire vein. Postmart black and conical, a third of the half the length of the stigmal which inal vein distinct, short, not quite marginal. Marginal cilia of the fore wing a litth the length of the 
With the habitus of a Pirenine, Tetracampine or Spalangia. Caudal tibial spur single, small. Proximal tarsal joint longest of the four. Sculpture very fine, usual for the group. Coxæ elongate. Antennæ 10 -jointed with two ring-joints.

Stigmatotrastichus emersoni new species. Genotype.

Female: Length, about $0.90 \mathrm{~mm}$. Very dark æneous black, the scape, the pedicel except above, coxæ, tarsi except the last joint, tips of tibiæ, proximal third of caudal tibiæ (and very much less of the other tibiæ) and the abdominal petiole, white. Fore wings embrowned (most deeply under the marginal vein) but clear under distal threefourths of the submarginal vein and with a hyaline, subnaked crossstripe (abbreviated caudad) from the apex of the postmarginal vein (crossing the stigmal). Pedicel elongate, over twice longer than wide, a little over half the length of the scape. Funicle 1 subequal to the pedicel, 2 much shorter, somewhat longer than wide, 3 subquadrate, as long as club 3 (the longest of the club) which ends in an acute, nipplelike point. Bulb of scape black. Ring-joints sub-equal, distinct.

Described from a female on a tag in the U. S. N. M., labelled "Paraspalangia annulipes Ashmead, female type. Type No. 12731, U. S. N. M. College Station, Texas, Banks, September."

Type: Catalogue No. 12731, U. S. N. M., the foredescribed female and a slide bearing an antenna, a fore wing and the caudal legs.

Paraspalangia Ashmead was proposed as a new genus in the Spalangiinæ but no species was ever described though one was named as above.

\section{Parecrizotes new genus.}

Female: In Ashmead's table to the Pireninæ runs to Ecrizotes Foerster but differs from that genus in having the marginal vein distinctly thickened at base, the thickening conical distad and occupying about half of the length of the vein which is somewhat less than twice the length of the well-developed, curved stigmal, the latter a little shorter than the postmarginal. Ovipositor valves extruded for a length about half that of the abdomen, the latter conical and a little longer than the rest of the thorax. Parapsidal furrows complete, deep, Scutellum simple. Propodeum very short at the meson, lengthening laterad, practically noncarinate. Pronotum subtransverse-quadrate. Strigil strong, also the caudal tibial spurs, the latter unequal, not enlarged especially. Legs moderate. Head wider than the thorax, the vertex wide, the antennæ inserted near the clypeus, 11-jointed with oneminute ring-joint, the five funicle joints enlarging distad, the wider, large-ovate club nearly as long as the funicle. Mandibles palmately 4-dentate. Maxillary palpi 4-jointed. Scutellum with a lateral groove like the second one of the Tetrastichini. Head somewhat longer than wide. 
The male differs in having the antennæ filiform, 12-jointed with two minute ring-joints, the funicle 6 -jointed, the club 2 -jointed and terminating in an obtuse nipple; funicle and club joints clothed with long soft hairs, more or less 2 -whorled (less numerous in the female).

Parecrizotes marylandensis new species. Genotype.

Female: Length, $1.00 \mathrm{~mm}$.

Lustrous black, the head and thorax distinctly scaly; cephalic knees, proximal one or two tarsal joints, a band at base of caudal tibia and apex of scape, silvery white. Wings hyaline, the venation dusky pallid, the swelling of the marginal vein black. Mandibles reddish yellow at apex, the teeth decreasing in size from the first, acute. Pedicel a little longer than wide, slightly larger than funicle 5 which is a little wider than long; funicles 1-3 like large ring-joints but much larger than the real ring-joint; 4 not much smaller than 5. Club without a terminal nipple.

The male differs in having the entire scape black; funicle 1 is largest, cup-shaped, 4-6 twice wider than long. Club nearly equally divided. Last joint of maxillary palpus elongate, equal to the other three taken together.

Described from one male, three females captured by sweeping meadows, September 28, 1915, at Hillmead, Prince George County, Maryland. A rather common species. There is a pair in the U. S. N. M., labelled "Henicetrus annulipes Ashmead, Virginia, October 10, 1880," and a female labelled "virginiensis Ashmead, Arlington, Va., June 1884."

Types: Catalogue No. 19945, U. S. N. M., a female on a tag plus a slide bearing a pair, a male and female head and female caudal tibiæ. The types were collected in the Maryland locality.

Roptrocerus rectus Provancher.

A number of specimens of both sexes, Ithaca, New York, reared in connection with Ips pini, July. There is considerable variation in color; the antennæ may be reddish brown nearly to the club, the ovipositor all black, the legs all yellow brown except the coxæ. The caudal legs are usually metallic, the caudal tibiæ with a broad yellow band just below the knee.

The male is much smaller and has a rather narrow yellow stripe across the abdomen very near base; its antennæ are filiform, 13-jointed with two ring-joints; funicle 1 is about twice longer than wide, longest of the flagellum while 6 is a half longer than wide or nearly, longer than the short pedicel. Otherwise about as in the female. The marginal vein in both sexes is thicker proximad, somewhat as in Muscidifurax but not so noticeably. A female from Michigan bore no carinæ on the propodeum.

An unstable, widely distributed species probably introduced from Europe. 


\section{Achrysocharella obscurinotata new species.}

Female: Length, about $0.90 \mathrm{~mm}$.

Bright golden yellow, the wings hyaline, the antennæ black except proximal three-fourths of the scape dorsad; the other portion of the scape and the pedicel dusky, the latter yellowish at apex. Valves of the ovipositor extruded slightly, black. Abdomen above with four small transverse dusky spots, along each side of the meson (thus four pairs or eight in all), the first smallest, some little distance out from base, the fourth at about middle and widest apart from its reciprocal, about twice wider than long, 1 barely wider than long, absent in one specimen. Scutellum with two black bristles distad, the scutum with four in a rectangle, the caudal two longest. Mandibles with three spreading teeth, long, pale, reddish at apex. Postmarginal vein subequal in length to the stigmal. Propodeum noncarinate. Pedicel nearly a half longer than wide, subequal to funicle 2 , funicle 1 nearly twice longer than wide; club joints nearly equal, each a little shorter than the funicle 2 , club 3 with a distinct terminal nipple which is not half of its length. Flagellum with long, scattered hairs, some stout, mostly very slender. Head and thorax scaly. Parapsidal furrows incomplete.

Described from two females captured by sweeping Solidago, Eupatoria and so forth, September 27, 1915, at Hillmead, Glenndale, Prince George County, Maryland.

Types: Catalogue No. 19946, U. S. N. M., the above specimens on tags, the two heads on a slide.

\section{Eupelminus coleopterophagus new species.}

Female: Length, $2.50 \mathrm{~mm}$., excluding the ovipositor which is extruded a fourth the length of the abdomen and is white centrally.

Differs from meteori Gahan in having most of the thorax metallic; from dryorhizoxenii Ashmead about the same; the body is slenderer than with either of these species; from an identified female of epicaste Walker in having the ovipositor somewhat shorter, the scutum entirely metallic mesad, the legs lighter in places, the pedicel longer.

Subapterous, the distal half of the small wings fuscous. Metallic green, the abdomen dark purple, encircled at base by a broad silvery band. The following parts reddish yellow: Scape, axillæ, basal third of scutellum, lateral ridges of the scutum, propleurum, proventer cephalad, mesopleurum cephalad, tarsi, cephalic femora and tibiæ interiorly, tips of tibiæ and middle femora except above. White part of valves of the ovipositor somewhat longer than either black part, the latter short. Scutum without a median ridge. Funicle 1 somewhat wider than long, 3 and 4 longest, subequal to each other and to the pedicel, 2 twice longer than wide, a little shorter than 3,7 quadrate, 8 slightly wider 
than long. Scape not compressed. Axillæ a little separated. Head and thorax scaly, Scutellum plane. No raised area mesad on cephalic scutum. Segments of abdomen caudad excised slightly at the meson.

Described from four females reared in connection with the strawberry weevil, St. Paul, Minnesota (S. Marcovitch).

Types: Catalogue No. 19947, U. S. N. M., the above specimens on two tags, a head on a slide.

\section{Eupelmus neomexicanus new species.}

Female: Length, $2.60 \mathrm{~mm}$., the ovipositor just projecting beyond the tip of the abdomen, white.

Dark metallic green, the wings hyaline; legs, prepectus, mesopleurum and a moderately broad stripe across the abdomen just out from base but more or less distinct, reddish yellow. Venation pale yellowish. Tarsi white, the last joint dusky. Tip of caudal tibiæ, white. Postmarginal and stigmal veins subequal. Antennæ black, the scape not noticeably compressed; funicle 1 somewhat longer than wide, 3 and 4 longest, subequal, neither as long as the pedicel which is over $21 / 2$ times longer than wide at apex; funicle 2 a third longer than wide, 3 twice longer than wide; 8 slightly wider than long. Head and thorax finely scaly, the axillæ and scutellum uniformly coarser. Abdomen scaly like the scutum, the latter with a lateral ridge but no median (or else it is very obscure and delicate). Raised, triangular part of the scutum cephalad not with a different sculpture. Segment 2 of abdomen deeply incised at meson of its caudal margin, the following segments less and less so.

Described from two females in the U. S. N. M., labelled "Las Cruces, New Mexico."

Types: Catalogue No. 19948, U. S. N. M., the above specimens on tags plus a slide with fore wings and antennæ.

\section{Hemænasoidea new genus.}

Female: In my table of the earth's encyrtine genera runs to Hemanasius Ashmead but differs from that genus in having the head much longer than wide, the eyes very long, six times longer than the distinct yet short cheeks, the head lenticular, the frons moderately narrow. Mandibles with three acute teeth, the first two equal, the third short. Ovipositor extruded nearly half the length of the abdomen. Marginal vein slightly longer than wide; the postmarginal moderately long but somewhat shorter than the stigmal. Hairless line of fore wing narrow. Axillæ barely separated. 
Hemænasoidea oculata new species.

Female: Length, about $1.75 \mathrm{~mm}$., excluding the ovipositor.

Dull honey yellow, the following embrowned parts: Center of cephalic pronotum, scutum, abdomen, tip of ovipositor valves, tibiæ except at ends (caudal tibiæ much darker, purplish), scape, pedicel and funicles 1-2. Fore wings embrowned at base and from the bend of the submarginal vein distad to about a point as far distad of the apex of the stigmal vein as that vein is long; this central infuscation is followed by a discal (longer than wide) naked area inclosed by discal cilia; otherwise the fore wing very finely ciliate discally but naked between the two infuscations. Venation dusky yellow, Scape reaching to the cephalic ocellus, cylindrical, the pedicel two and a half times longer than wide at apex, longer than any funicle joint; funicle 1 longest, a half longer than wide, 5 slightly longer than wide, 6 quadrate. Club about half the length of the funicle, obliquely truncate, not enlarged. Body finely scaly. Scutellum with a few scattered, rather coarse hairs. Pronotum moderately large. Axillæ large. Legs slender. Middle femora, tarsi (except last joint), ovipositor valves (except at apex) and antennæ distad, whitish. Club truncate from base of joint 1 .

Described from a female on a slide in the U. S. N. M., labelled "Reared from Pseudococcus citri on bamboo, Manila, Compere, July, 1909. No. 24.

Type: Catalogue No. 19949, U. S. N. M., the above specimen on a slide. 


\section{$2 \mathrm{BHL}$ Biodiversity Heritage Library}

Girault, Alexandre Arsène. 1916. "New miscellaneous chalcidoid Hymenoptera with notes on described species." Annals of the Entomological Society of America 9, 291-308. https://doi.org/10.1093/aesa/9.3.291.

View This Item Online: $\underline{\text { https://www.biodiversitylibrary.org/item/43630 }}$

DOI: https://doi.org/10.1093/aesa/9.3.291

Permalink: https://www.biodiversitylibrary.org/partpdf/18739

\section{Holding Institution}

Smithsonian Libraries

\section{Sponsored by}

Smithsonian

\section{Copyright \& Reuse}

Copyright Status: NOT_IN_COPYRIGHT

This document was created from content at the Biodiversity Heritage Library, the world's largest open access digital library for biodiversity literature and archives. Visit BHL at https://www.biodiversitylibrary.org. 